\title{
TECHNIQUE OF ASSESSMENT OF EXPEDIENCY OF APPLICATION OF OUTSOURCING
}

Ilnour I. Farkhoutdinov ${ }^{1}$

Alexey G. Isavnin ${ }^{2}$

\begin{abstract}
One of the main criteria of successful application of production outsourcing is competent definition of degree of expediency of use of this tool at the enterprise. Reasonable combination of outsourcing and insourcing where management of them is constructed on in advance defined accurate principles, and identification of exact borders of outsourcing are pledge of effective application of this model of management at the enterprise. Therefore there is a need for a reliable technique which would allow to define decision on use of this tool.The offered technique is based on matrix approach.In the real work as authors the technique of an assessment of expediency of application of production outsourcing at the enterprise is offered.Results of the real work can be of interest to heads of the large industrial enterprises, and also can be useful to further scientific researches in the field of sourcing. The offered technique allows to define competently the product components which are subject to transfer to outsourcing.
\end{abstract} competently the product components which are subject to transfer to outsourcing. The purpose of this work is development of a technique of an assessment of expediency of application of production outsourcing at the enterprise, and also definition of major factors of adoption of the administrative

Keywords: expediency of outsourcing, strategic management, outsourcing matrix; insourcing; industrial outsourcing.

\section{Introduction}

\footnotetext{
${ }^{1}$ Kazan Federal University, Naberezhnye Chelny institute.e-mail: ilnour1986@inbox.ru. tel.: +79600701168.

${ }^{2}$ Kazan Federal University, Naberezhnye Chelny institute.e-mail: ilnour1986@inbox.ru. tel.: + 79600701168.
} 
From the moment of practical application of the tool under the name "outsourcing" and in process of its development in scientific and practical literature, process of formation and formation of the new direction in economic science which it is possible to call as "economy of sourcing" began. The economy of sourcing is devoted to development and studying of models of optimum use of factors of production therefore one of the main criteria of successful application of production outsourcing is competent definition of degree of expediency of use of this tool at the enterprise. Reasonable combination of outsourcing and insourcing where management of them is constructed on in advance defined accurate principles, and identification of exact borders of outsourcing are pledge of effective application of this model of management at the enterprise [1]. Therefore there is a need for a reliable technique which would allow to define 2. competently the product components which are subject to transfer to outsourcing.

The purpose of this work development of a technique of an assessment of expediency of application of production outsourcing at the enterprise, and also definition of major factors of adoption of the administrative decision on use of this tool.

\section{Materials and methods}

\section{The analysis of the existing models}

The analysis of scientific and practical literature on this subject allowed to allocate the following main and most widespread techniques of an assessment of expediency of application of outsourcing at the enterprise:

1. The Price water house Coopers model which is based on use of the following factors at decision-making on outsourcing use: competitive and strategic importance of an asset [2]. 
Competitive

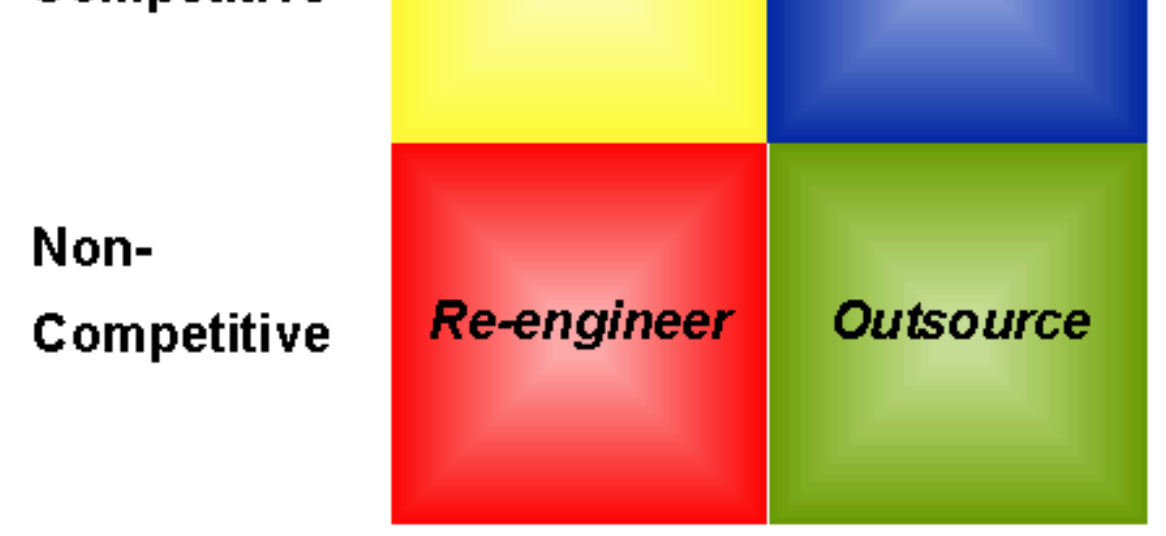

\section{Strategic Non-Strategic}

346

Fig. 1. Model of PricewaterhouseCoopers

3. Card of agreements with the is based on use of the following factors supplier of Clinton B.D. and S.C. Del at decision-making on outsourcing use: Vecchio. The card of agreements with proximity of the supplier and risk of loss the supplier of Clinton and Del Vecchio of control [3].

4. 


\section{Supplier Arrangem ents Map* \\ (Cosourcing Compared to 7 Other Supply Chain Arrangements)}

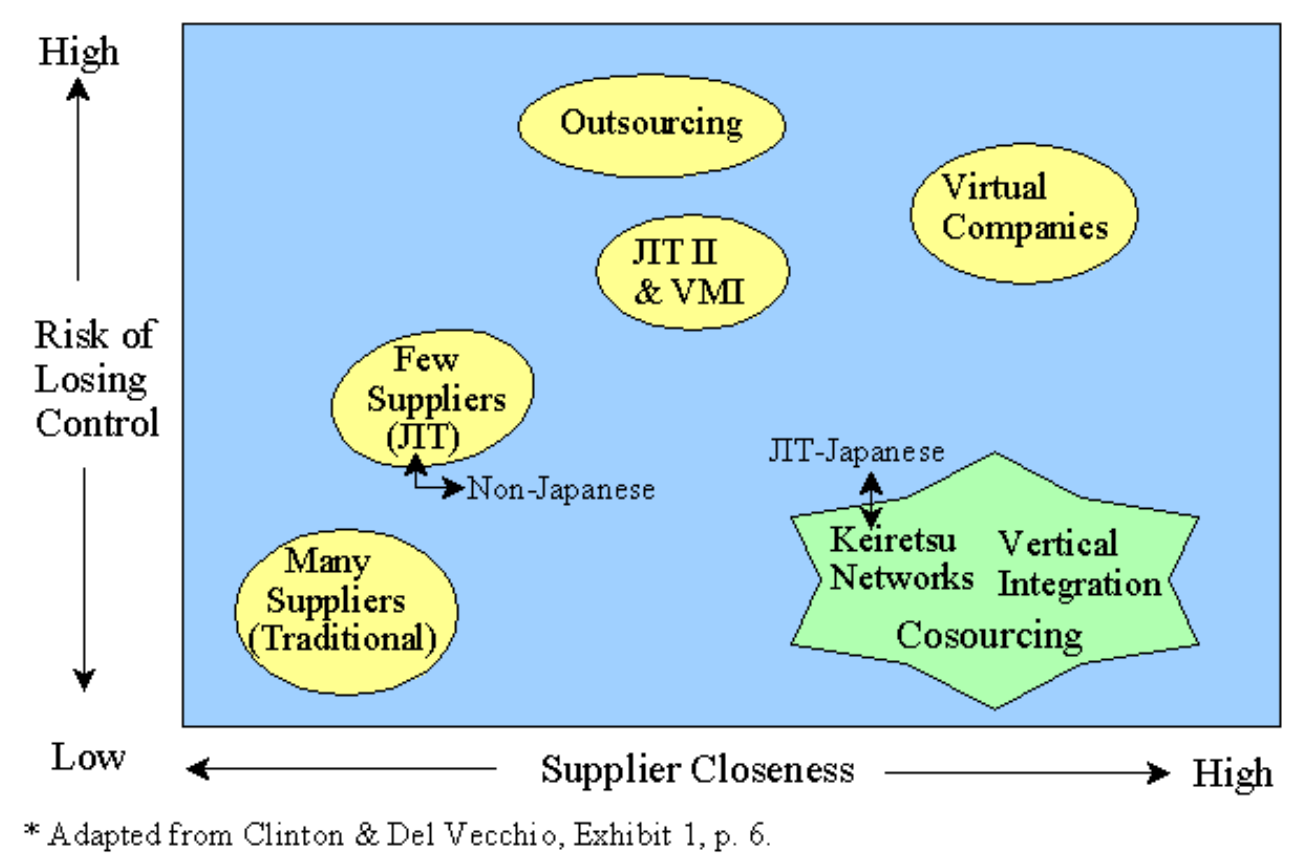

Fig. 2. Card of agreements with the supplier of Clinton B.D. and S.C. Del Vecchio

5. Matrix of outsourcing of K. outsourcing and insourcing: potential Vitasek and M. Ledyard. This matrix is value for the organization and based on use of the following factors at organizational expert knowledge [4]. decision-making on application of

6.

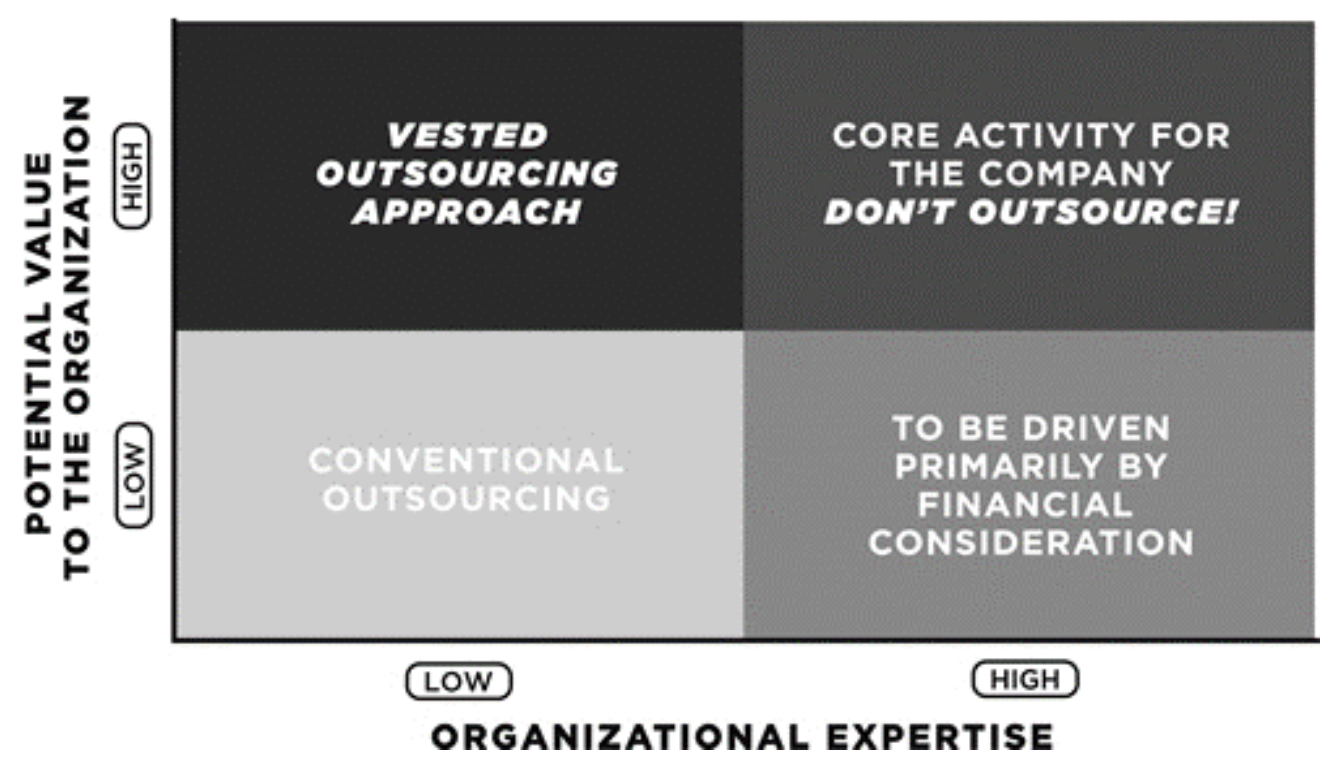


Fig. 3. Matrix of outsourcing by K. Vitasek and M. Ledyard

7. Matrix of outsourcing of Ronan decision-making on application of McIvor, Paul K. Humphreys, Anthony P. outsourcing and insourcing: relative Wall, Alan McKittrick. This matrix is possibility of realization and importance based on use of the following factors at of process to competitive advantage [5]. 8.

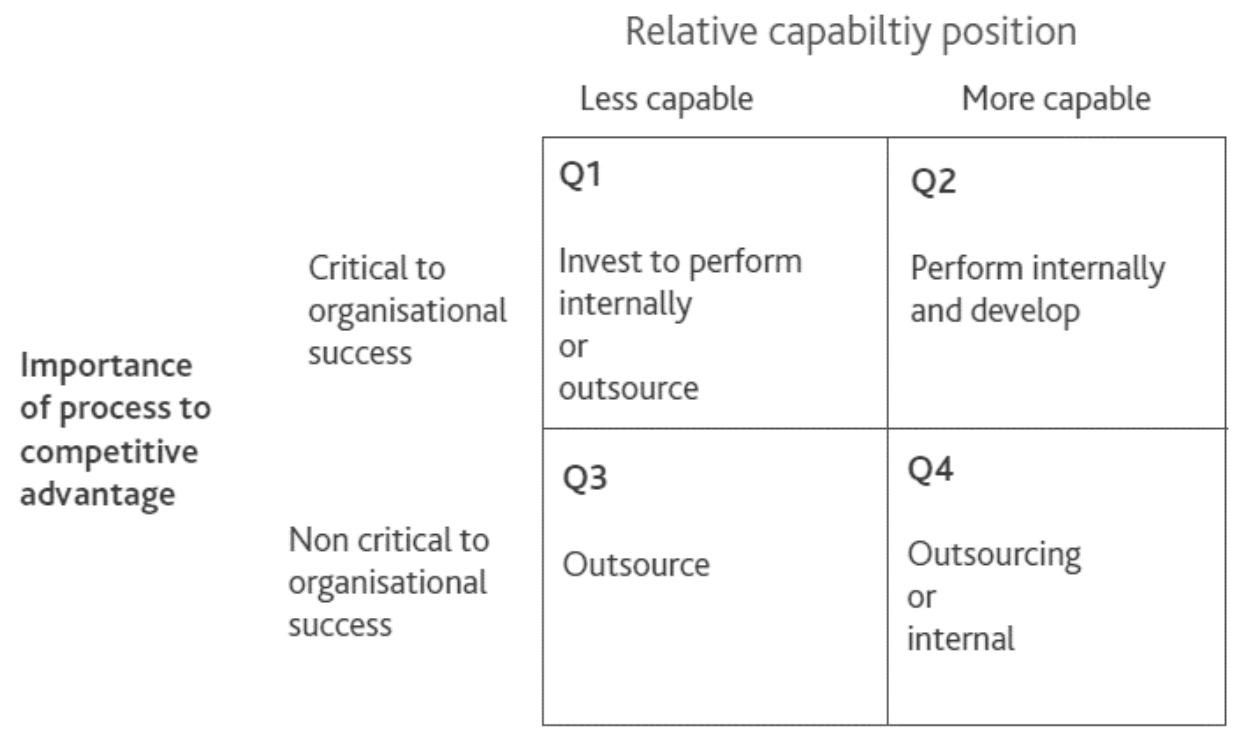

Fig. 4. Matrix of outsourcing by Ronan McIvor, Paul K. Humphreys, Anthony P. Wall, Alan McKittrick

\section{Matrix of outsourcing of Mingu}

Kang, Xiaobo Wu, Paul Hong. This matrix is based on use of the following factors at decision-making on application of outsourcing and insourcing: risk of outsourcing and influence on profit [6]. 


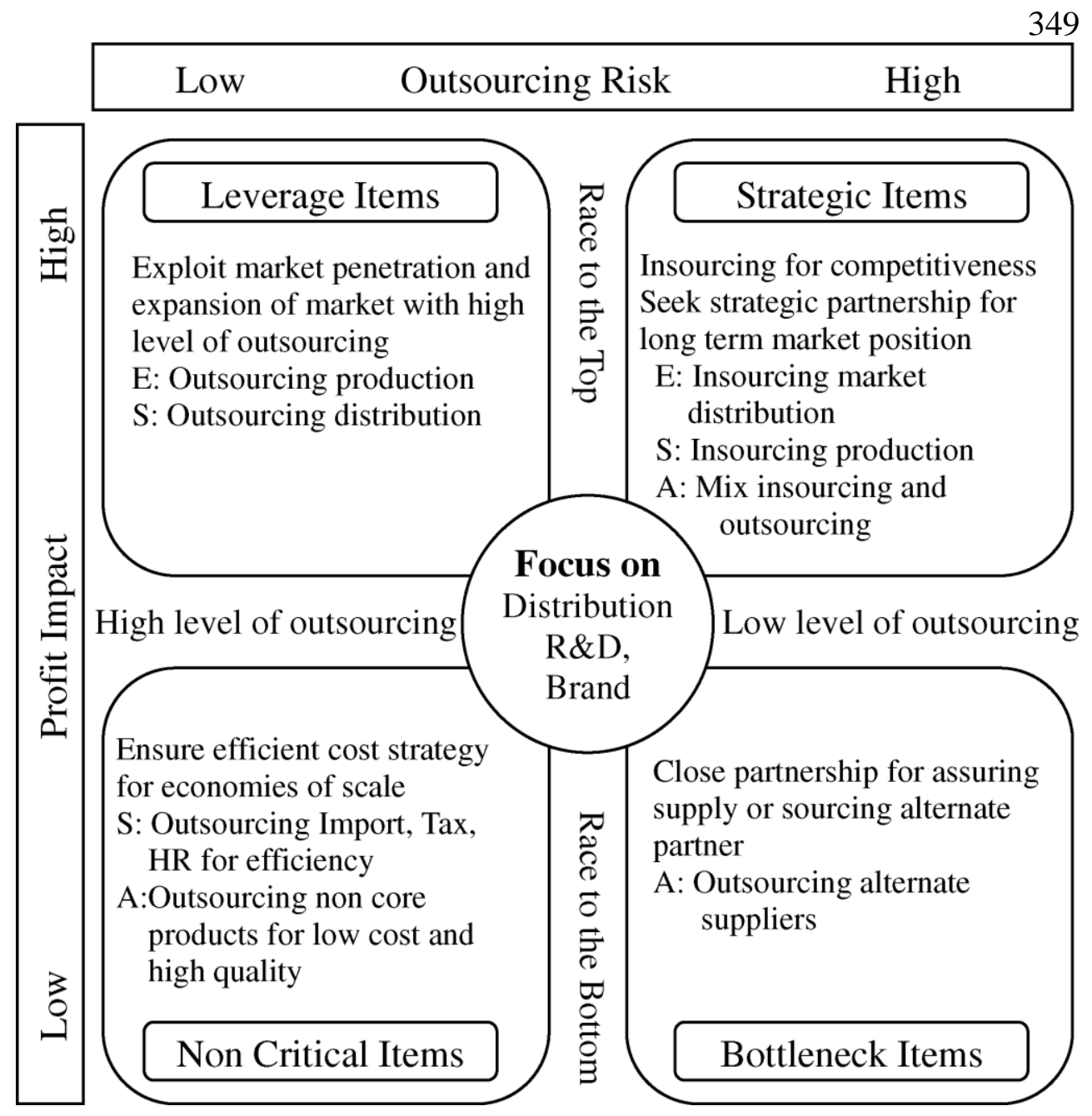

Fig. 5. Matrix of outsourcing by Mingu Kang, Xiaobo Wu, Paul Hong

Also in scientific and practical

literature there are Moiseeva N.K., Malyutin O.N. and Moskvin I.A. model [7], Mitrofanova E.V. model [8] and others.

It should be noted that all models given above are kinds of matrix approach as "the outsourcing matrix" is the most widespread and demanded method. However an essential lack of "an outsourcing matrix" is the twofactoriality [9].
Application of production outsourcing in the Russian industry most often is followed by restructuring of the enterprise [10]. Therefore, for definition of the components of a product which are subject to transfer to outsourcing it is necessary to understand how strategically significantly for the enterprise production of this component and what profit it makes for the company. All listed above models are based a little on other factors, 
inapplicable for this type of outsourcing as they, were generally developed for an assessment of expediency of application of outsourcing of business functions. Here we represent the following technique of an assessment of expediency of application of restructuring production outsourcing at the enterprise.

\section{Results and discussion}

This technique is a kind of matrix approach which is based on use of the following factors at adoption of the administrative decision on use of restructuring production outsourcing: strategic importance and profitability. We will consider in more detail each factor.

\section{Strategic importance}

To define how strategically significantly for the enterprise production of this or that component of a product, we will make the table in which the main criteria of an assessment of the strategic importance, levels of points and their values (table 1) have to be designated.

Table 1. Criteria of an assessment of the strategic importance of a component

\begin{tabular}{|c|l|c|c|c|c|}
\hline \multirow{2}{N}{ o } & \multicolumn{1}{|c|}{ Criteria of strategic importance } & \multicolumn{4}{|c|}{ Points } \\
\hline & & $\boldsymbol{B}_{1}$ & $\boldsymbol{B}_{2}$ & $\cdots$ & $\boldsymbol{B}_{\boldsymbol{n}}$ \\
\hline 1 & Criterion 1 $\left(K_{1}\right)$ & $x_{11}$ & $x_{12}$ & $\cdots$ & $x_{1 n}$ \\
\hline 2 & Criterion 2 $\left(K_{2}\right)$ & $x_{21}$ & $x_{22}$ & $\cdots$ & $x_{2 n}$ \\
\hline$\cdots$ & $\cdots$ & $\cdots$ & $\cdots$ & $\cdots$ & $\cdots$ \\
\hline $\mathrm{m}$ & Criterion $\mathrm{m}\left(K_{m}\right)$ & $x_{m 1}$ & $x_{m 2}$ & $\cdots$ & $x_{m n}$ \\
\hline
\end{tabular}

Some explanations to table 1:

$\checkmark \quad$ Criteria of an assessment of the strategic importance and their quantity for each company are individual. It is possible to give the following criteria which can be applied at the enterprise as an example:

the importance of a component for a brand,

the importance of a component for the final product, 
market of suppliers of a component,

component prospects on the future and others.

In other words, criteria are defined proceeding from strategy of the enterprise. For example, on OJSC "KAMAZ", in view of developed in Russia and the CIS countries of a dealer network [11], one of criteria of an assessment of the strategic importance of a component is "The importance in the market of spare parts".

Each company determines the level of points and their value for itself individually. The most convenient is the three-level system of points: low, average and high point; where the low point is equal 1 , the average is equal 2 and the high point is equal 3 .

$$
\checkmark \quad \text { Matrix } \quad X=\left(x_{i j}\right)_{i=1, j=1}^{m, n}
$$

(where $i-$ index by amount of criteria; $j$ - index by number of levels of points) represents set of characteristics of each criterion of $K_{i}$ to each level of points of $B_{j}$.

For descriptive reasons we will present an example of how the table of criteria of an assessment of the strategic importance (table 2) completed at the enterprise can look.

Table 2. An example of the made table at the enterprise

\begin{tabular}{|c|c|c|c|c|}
\hline \multirow[b]{2}{*}{ № } & \multirow{2}{*}{$\begin{array}{c}\text { Criteria of } \\
\text { strategic } \\
\text { importance }\end{array}$} & \multicolumn{3}{|c|}{ Points } \\
\hline & & $\begin{array}{c}\text { Low point } \\
\qquad\left(B_{1}=1\right)\end{array}$ & $\begin{array}{l}\text { Average point } \\
\qquad\left(B_{2}=2\right)\end{array}$ & $\begin{array}{l}\text { High point } \\
\qquad\left(B_{3}=3\right)\end{array}$ \\
\hline 1 & $\begin{array}{l}\text { The importance } \\
\text { for a brand }\end{array}$ & $\begin{array}{l}\text { The component } \\
\text { has weak impact } \\
\text { on a brand }\end{array}$ & $\begin{array}{l}\text { The component has } \\
\text { average impact on a } \\
\text { brand }\end{array}$ & $\begin{array}{l}\text { The component } \\
\text { has strong impact } \\
\text { on a brand }\end{array}$ \\
\hline 2 & $\begin{array}{l}\text { Prospects on the } \\
\text { future }\end{array}$ & $\begin{array}{l}\text { The component } \\
\text { will be made less } \\
\text { than } 5 \text { years }\end{array}$ & $\begin{array}{l}\text { The component will } \\
\text { be made from } 6 \text { to } 14 \\
\text { years }\end{array}$ & $\begin{array}{l}\text { The component } \\
\text { will be made more } \\
\text { than } 15 \text { years }\end{array}$ \\
\hline 3 & $\begin{array}{l}\text { Market } \\
\text { outsourcers }\end{array}$ & $\begin{array}{l}\text { Number of } \\
\text { outsourcers more } \\
\text { than } 8\end{array}$ & $\begin{array}{l}\text { Number of } \\
\text { outsourcers from } 3 \\
\text { to } 7\end{array}$ & $\begin{array}{l}\text { Number of } \\
\text { outsourcers less } \\
\text { than } 2\end{array}$ \\
\hline
\end{tabular}




\begin{tabular}{|c|c|c|c|c|}
\hline 4 & $\begin{array}{l}\text { The importance } \\
\text { for the final } \\
\text { product }\end{array}$ & $\begin{array}{l}\text { The component is } \\
\text { established only } \\
\text { as an option }\end{array}$ & $\begin{array}{l}\text { The component can } \\
\text { be in the form of the } \\
\text { additional decision } \\
\text { or obligatory at } \\
\text { some options } \\
\text { (complete sets) of } \\
\text { the final product }\end{array}$ & $\begin{array}{l}\text { The component is } \\
\text { irreplaceable part } \\
\text { of a product }\end{array}$ \\
\hline
\end{tabular}

After definition of the main criteria of an assessment of the strategic importance, the analysis of components of a product by each criterion where the level of points corresponding to it is defined is carried out and value of this level is appropriated. Further for each component the arithmetic average value of points which shows the relative level of the strategic importance of a component for the enterprise (table 3 ) is defined.

Table 3. Assessment of the strategic importance of components

\begin{tabular}{|c|l|c|c|c|c|}
\hline № & Components & $\begin{array}{c}\text { Criterion 1 } \\
\left(\boldsymbol{K}_{\boldsymbol{l}}\right)\end{array}$ & $\ldots$ & $\begin{array}{c}\text { Arithmetic } \\
\text { Criterion m } \\
\left(\boldsymbol{K}_{\boldsymbol{m}}\right)\end{array}$ & $\begin{array}{c}\text { average value } \\
\text { of points } \\
(S B)\end{array}$ \\
\hline 1 & Component 1 & $B_{j}$ & $\ldots$ & $B_{j}$ & $S B_{1}$ \\
\hline 2 & Component 2 & $B_{j}$ & $\ldots$ & $B_{j}$ & $S B_{2}$ \\
\hline$\ldots$ & $\ldots$ & $\ldots$ & $\ldots$ & $\ldots$ & $\ldots$ \\
\hline $\mathrm{p}$ & Component $\mathrm{p}$ & $B_{j}$ & $\ldots$ & $B_{j}$ & $S B_{p}$ \\
\hline
\end{tabular}

Further we determine profitability level.

\section{Profitability}

Profitability represents an indicator of the economic importance of a component for the enterprise. As this indicator such indicators as profitability of production, profitability of sales, marginal profitability and others can be 
applied. Each enterprise defines for itself an indicator convenient to it. For example, OJSC "KAMAZ" defined for itself an indicator of marginal profitability [11].
After definition of arithmetic average value of points and profitability the summary table which can look as follows (table 4) is under construction:

Table 4. Example of the summary table.

\begin{tabular}{|c|l|c|c|}
\hline № & \multicolumn{1}{|c|}{ Components } & $\begin{array}{c}\text { Arithmetic average } \\
\text { value of points, } \\
\text { units }\end{array}$ & Profitability, \% \\
\hline 1 & Component 1 & 2,20 & $15 \%$ \\
\hline 2 & Component 2 & 2,45 & $25 \%$ \\
\hline$\cdots$ & $\cdots$ & $\cdots$ & $\cdots$ \\
\hline $\mathrm{p}$ & Component $\mathrm{p}$ & 1,95 & $30 \%$ \\
\hline
\end{tabular}

Having made the summary table on the analyzed components, we build the dot schedule in the Cartesian system of coordinates where the provision of each component of a product occupied on the level of the strategic importance and profitability is displayed (figure 6). 


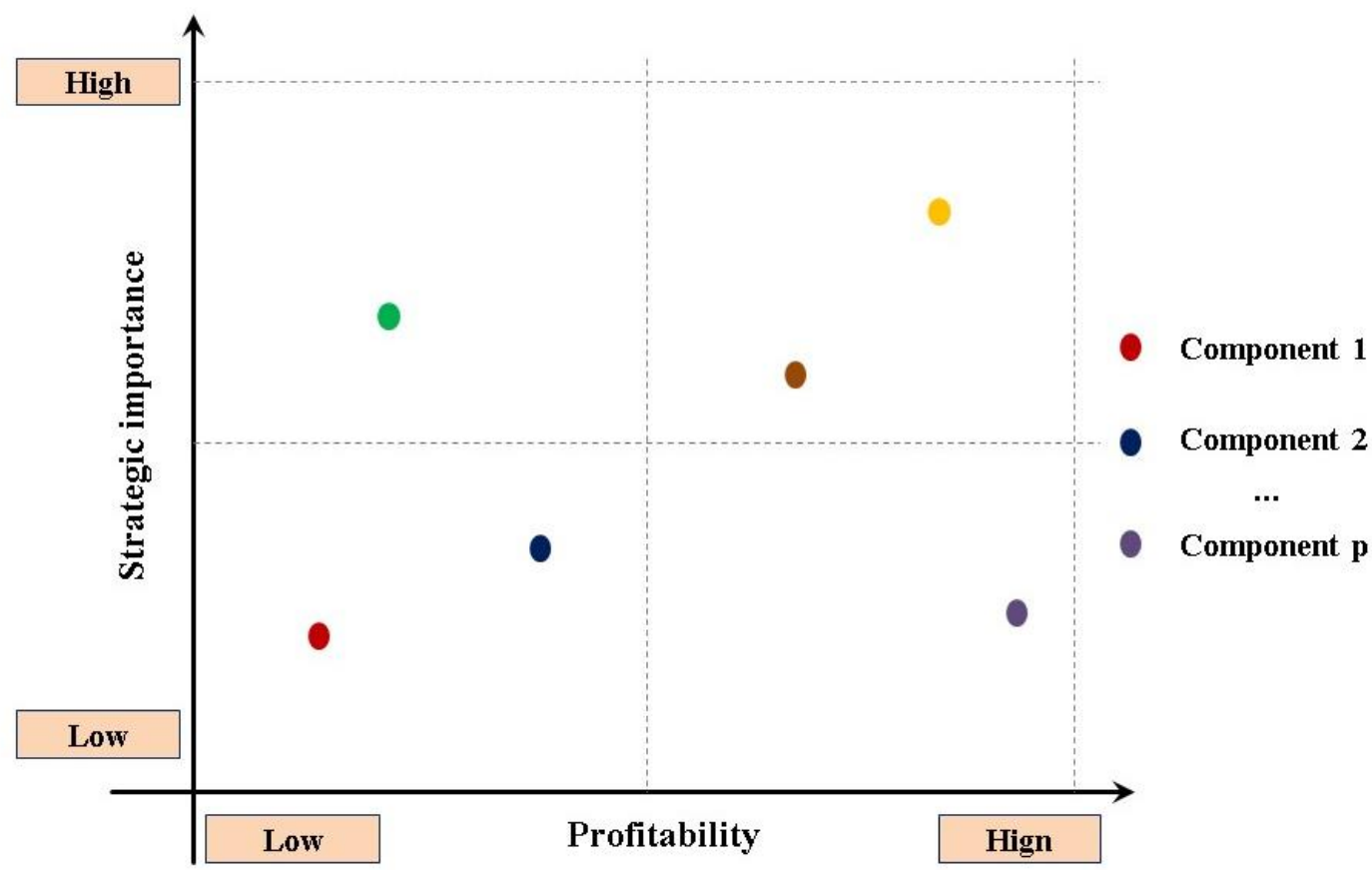

Fig. 6. Spot chart

The following step is submission of this schedule in the form of an outsourcing matrix. The matrix of outsourcing can be both symmetric $(2 \times 2$, $3 \times 3$, etc.), and asymmetrical $(2 \times 3,3 \times 2$, etc.). The most evident and idle time for use by a matrix is a symmetric matrix of outsourcing of dimension $2 \times 2$ : $M=\left(m_{i j}\right)_{i=1, j=1}^{2,2}$. We will construct it, proceeding from our dot schedule (figure $7)$. 


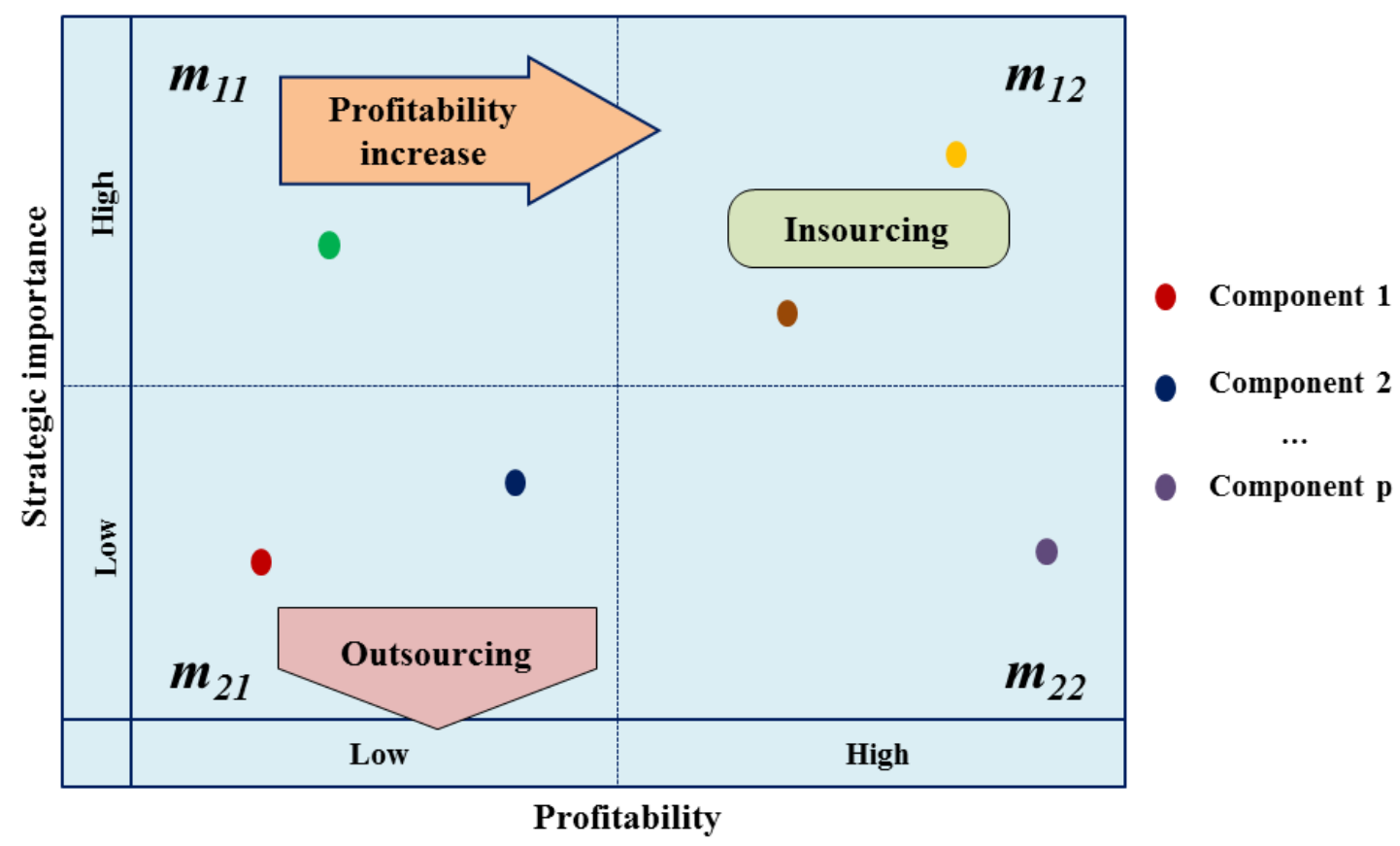

Fig. 7. Matrix of appropriateness of outsourcing

From figure 7 it is visible that all components belonging to $m_{21}$ matrix element are exposed to a conclusion in outsourcing in view of the low strategic importance and profitability. The components opposite to them belonging to the $m_{12}$ element which have the high strategic importance and profitability, remain in the enterprise (insourcing).

As for other components, the components belonging to the $m_{11}$ element have the high strategic importance for the enterprise, but low profitability therefore it is expedient to perform optimization of designs of these components and/or technological process for the purpose of profitability increase. The components belonging to the $m_{22}$ element can or remain in the enterprise, or be transferred to outsourcing depending on policy of the enterprise.

If the company chooses other type of a matrix with other dimension, versions of decisions on these or those components can be defined by the company individually, proceeding from policy of the enterprise for a component or depending on the reasons of application of production outsourcing.

\section{Conclusions}

The presented technique of an assessment of expediency of application of production outsourcing at the 
enterprise is a kind of matrix approach therefore its only shortcoming, as well as

\section{References}

other matrix models, the two-factoriality 1)

is. However for application of Isavnin A.G., Farkhoutdinov I.I. Some restructuring production outsourcing which, is generally directed on optimization of floor spaces and decrease in costs of production, existence of factors "the strategic importance" and "profitability" is sufficient.

The main advantage of the presented model is ability to integrate with other existing outsourcing matrixes. In particular, the company can construct a matrix of any dimension (symmetric or asymmetrical) with application of the decisions on a component borrowed from other models. The technique allows to define and retain competently only those components of a product which are favorable to production and are strategically significant for the enterprise.

\section{Acknowledgements}

models of source maneuver // International scientifically-practical conference «Advanced scientific development - 2012», volume 3, Prague, Czechia, 2012. pp. 7-10. URL: http://www.ukrnauka.ru/NNP/28-082012_2_A4_tom-3.pdf (reference date: 24/09/2012).

Shelukhin I.S. Criteria of transition to outsourcing of the industrial enterprises // Report theses at a seminar «Industrial cooperation and outsourcing», 2003. URL:

http://www.iteam.ru/articles.php?pid=1 $\&$ tid $=2 \& \operatorname{sid}=17 \& \mathrm{id}=198$

Clinton, B. D. and S. C. Del Vecchio. 2002. Cosourcing in manufacturing. Journal of Cost Management (September/October): 5-12. URL: http://maaw.info/ArticleSummaries/Art SumClintonDelVecchio02(1).htm

The work is performed according to the

Russian Government Program of Competitive Growth of Kazan Federal University.

Kate Vitasek, Mike Ledyard and Karl B. Manrodt, Vested

Outsourcing:

Five Rules That

Will 
Transform Outsourcing, (New York:

Palgrave Macmillan, 2010), pp. 10-11.

Ronan McIvor, Paul K. Humphreys, Anthony p. Wall, Alan McKittrick. A study of performance measurement in the outsourcing decision // Research executive summaries series, Vol. 4, Issue 3.

Mingu Kang, Xiaobo Wu, Paul Hong. Strategic outsourcing practices of multinational corporations (MNCs) in China. // Strategic Outsourcing: An International Journal, - 2009, Vol. 2, pp. 240-256.

Moiseeva N.K., Malyutin O.N, Moskvin I.A. Outsourcing in development of business partnership; ed. Moiseeva N.K. - M.: Finance and statistics; INFRA-M, 2010. - pp. 240.

Mitrofanova E.V. How to optimize company business model // Magazine «Finance director», 2005. № 7-8. C.2532. URL: http://www.cfin.ru/management/strateg y/change/outsourcing.shtml

Firsova S.A. Tools of an assessment of outsourcing of non-core business functions, $2010 . \quad$ URL:

http://www.mrconsulting.ru/lib/articles/ $? \mathrm{id}=3$

Isavnin A.G., Farkhoutdinov I.I. Features of application of production outsourcing at the Russian automobile building enterprise, LAP LAMBERT Academic Publishing, AV Akademikerverlag $\mathrm{GmbH}$ \& Co. KG, 2013, Saarbrücken, Germany, ISBN 978-3-659-42197-6, 188 p.

Isavnin A.G., Farkhoutdinov I.I. Method for assessing the feasibility of using production outsourcing // Regional economy: theory and practice. 2013, №4 (283), p.16-20 